\title{
NEXUS BETWEEN REAL EXCHANGE RATE MISALIGNMENT AND ECONOMIC GROWTH: A CASE OF PAKISTAN
}

\section{Muhammad Asad Ali ${ }^{*}$ and Muhammad Aqil ${ }^{2}$}

\begin{abstract}
This study investigates the nexus between real effective exchange rate (REER) misalignment and the economic growth of Pakistan. It relies on a single equation model for estimating equilibrium exchange rate using the autoregressive distributive lags (ARDL) approach. The study further uses the growth equation to explore the effects of misalignment of RER on growth proxies. The data were obtained from the official websites of the World development indicator, IMF, Penn World Table, Pakistan Bureau of Statistics, and Ministry of Finance Pakistan. In terms of Trade, the data was available on three different bases in different editions of the economic survey of Pakistan. All unit values of imports and exports were changed as per new base 1991 so that the data from editions of survey becomes uniform. The study takes data from 1970 to 2020. The study findings show that gross capital formation, trade openness, and government spending have a substantial role in defining the equilibrium REER. The findings also identify a positive and significant effect of REER misalignment on the economic growth of Pakistan. This paper contributes by measuring the degree of misalignment of real exchange rates using the single equation approach which is rare in the case of Pakistani literature. The single equation approach not only measures the misalignment by PPP factor but also considers basic economic fundamentals such as trade openness, terms of trade, productivity differentials etc. The study further provides evidence of misalignment with economic growth over a longer period (1970-2020). The findings suggest the effective use of exchange rate policy to control exchange rate misalignment to get higher and more sustainable economic growth. The study is useful for policymakers in the long-term economic planning of Pakistan. The results can be generalized for other economies with similar features.
\end{abstract}

Keywords: Real Effective Exchange Rate Misalignment, Equilibrium Exchange Rate, REER, BEER, FEER, NATREX, Economic Growth, Single Equation Approach, Pakistan.

\footnotetext{
${ }^{1}$ PhD Scholar, Shaheed Zulfikar Ali Bhutto Institute of Science and Technology, Karachi, Pakistan, Email: muhammad.asad@szabist.edu.pk

${ }^{2}$ Assistant Professor, Shaheed Zulfikar Ali Bhutto Institute of Science and Technology, Karachi, Pakistan, Email: muhammad.aqil@ szabist.edu.pk

*Corresponding Author
} 


\section{INTRODUCTION}

Earlier in the $16^{\text {th }}$ to $18^{\text {th }}$ centuries, an ideology existed in the Western countries called Mercantilism economic thought. According to this thought, countries should maximize their exports and minimize their import to achieve economic growth and become rich (List, 2017). In today's world, international trade has become necessary as a country cannot produce everything in demand. Recent advancements in technology such as artificial intelligence in business, robotics, 3D printing, machine learning, and data analytics have made economies focus on transformation (Hoekman, 2021). Countries trade with each other for several reasons. The facilitation of international trade has given several advantages including the absolute and relative advantage of production, changes in foreign exchange reserves, access to foreign technology, fulfilling the gap of underproduction, and efficiently utilizing the over-produced goods. International trade competitiveness has been a great attraction to researchers for a long period and different theories have been developed from time to time.

The interdependence of the real exchange rate (RER) and the growth of an economy is obvious. However, Rodrik (2009) made a revolutionary change in the study of macroeconomic literature. The author was one of the pioneers who explored the impact of the RER misalignment on the economic growth. Several economic fundamentals determine the equilibrium RER for any economy. Any deviation from that equilibrium rate is termed as misalignment. Any intervention by government to achieve some goals can also result in the misalignment of RER can be a consequence of manipulating relevant economic fundamentals (Banerjee \& Goyal, 2021). The misalignment can also be a result of the selection of alternative equilibrium models as there are several methods of calculating equilibrium exchange rates and are still evolving (MacDonald, 2000). Among the various methods of estimation of equilibrium exchange rates, the notable approaches are discussed as follows.

Williamson (1985) is credited for the contribution of Fundamental Equilibrium Exchange Rate (FEER) approach. FEER works under the concept of internal and external balances in the economy. The internal balances are achieved through full employment production and a low general price level. The external balances are achieved through a sustainable balance of payment, sustainable external debt payment mechanism, and sustained capital account balance. The empirical model considers REER as a function of equilibrium current account and domestic and foreign output.

The Desired Equilibrium Exchange Rate (DEER) by Clark et al. (1994) is also one of the alternative and robust approach for equilibrium RER. The DEER uses elasticities of foreign and domestic output, and real exchange rate at their desired level for estimating equilibrium 
level. Furthermore, the Behavioral Equilibrium Exchange Rate (BEER) by MacDonald's (2000) is also considered a significant milestone in the literature. The BEER approach considers the cyclic and impermanent changes in the exchange rate and attempts elucidating its behavior. It also takes into account some unemployment levels of essential factors of real exchange rates. It is more robust than the FEER approach. Various studies can be found in the literature where the BEER approach has been employed (Detken et al., 2002; MaesoFernandez et al., 2002). The BEER model as applied by Clark and MacDonald used domestic real interest rate, foreign real interest rate, terms of trade, the ratio of price of non-traded to traded goods, net foreign assets, and the ratio between domestic and foreign government debt for equilibrium RER estimation.

BEER and FEER derived the equilibrium RER based on the prevailing fundamentals variables whereas current fundamentals may depart from sustainable level of variables in the long run. Thus, it was important to disseminate the variables in current and permanent equilibrium. Hence, the concept of Permanent Equilibrium Exchange Rate (PEER) was introduced. The PEER calculated the total misalignment whereas the previous approaches only used current misalignment. The literature also reports some studies to disseminate the variables into permanent and temporary elements. (Beveridge \& Nelson, 1981; Clarida \& Gali, 1994; Gonzalo \& Granger, 1995; Stock \& Watson, 1988).

If the cyclic and speculative factors are removed and there exists the natural rate of unemployment, the rate determined at that level is called the Natural Real Exchange Rate (NATREX) (Stein, 1994). This approach relies on the standard national income equation, the addition of capital stock and debt changes, and convergence to a long-run static rate (Siregar, 2011). However, this study chooses the single equation approach as employed by Baffes et al., (1999) and Edwards, (1989). This study uses terms of trade which is the ratio of unit value of exports to the unit value of imports, productivity differentials by finding the per capita GDP difference between Pakistan and the US, investment, government expenditures on tradeable and non-tradeable goods, degree of trade openness, net foreign assets, and interest rate differentials as deterministic factors of the equilibrium exchange rate.

After the estimation of the equilibrium exchange rate, the misalignment is estimated by subtracting the equilibrium exchange rate from the prevailing real effective exchange rate (REER). This study uses the Real Effective Exchange Rate for the estimation of misalignment. The REER is the weighted average of real exchange rates of different currencies. It takes into 
account the trading currencies and their price level along with the trade weights. Equation (a1) and (a2) below are the calculation formulas for REER.

$$
\begin{aligned}
Q^{R E E R} & =\sum_{i} \frac{\beta_{i} E_{i} P_{i}^{*}}{P} \ldots(a 1) \\
\beta_{i} & =\frac{X_{i}+M_{i}}{X+M} \ldots(a 2)
\end{aligned}
$$

Where $\beta_{i}$ represents the trade weights of each currency in foreign trade which is computed by taking the percentage of total trade with the specific country, $i$ as a percentage of total trade (sum of imports and exports $X+M), E$ is the nominal exchange rate, $P^{*}$ is the price level of a foreign country and $P$ is the domestic price level.

\section{LITERATURE REVIEW}

A vast amount of literature can be found on economic growth and also on determinants of the exchange rate, but a little number of studies can be seen on the effect of real exchange rate on economic growth. This section includes some of the studies done on this topic.

Tarawalie (2021) investigated the effect of episodes of misalignment on the economic growth of Sierra Leone taking the data from 1980 to 2018. The study found the significant impact of misalignment episodes on economic growth. Mamun et al. (2020) explored the effect of real exchange rate misalignment using a single equation approach for Turkey for the period of 1980 to 2016 using the ARDL approach. The results were similar to Dani Rodrik (2009) that is higher the undervalued real exchange rate, the higher the growth with linear relation. He also found evidence empirically that undervaluation accelerates the growth of any country. Another study explored how the real exchange rate misalignment affected the capital account openness for 60 developing countries for the period of 1980 to 2014 . The study found that the capital account openness affected exchange rate misalignment (Mahraddika, 2020).

Missio et al. (2015) took data from 1978 to 2007 and reported a positive and significant impact of competitive RER on economic growth. Also, Vieira \& MacDonald (2012) used the GMM panel growth model to find out the impact of exchange rate misalignments on the growth of GDP. The study reported that RER misalignment is positively affecting the GDP growth. They also included human capital in their growth equation. (Tarawalie, 2011) also showed a positive relationship between the two fundamentals. Berg and Miao (2010) investigated empirically the effect of real exchange rate misalignment using the Balassa Samuelson approach and found similar results as Rodrik (2008). In addition, Ahmed (2009) estimated the equilibrium exchange rate for the period of 1971 to 2007 and reported that the capital flows, trade openness, 
government spending, and terms of trade are substantial determinants of equilibrium RER for Pakistan.

Tyers et al. (2008) researched relationship between economic growth and effective exchange rate in China. They concluded that capital inflows have a significant effect on short-term RER, whereas demographic variables have weak long-term relationships in the composition of the labor force due to which the exchange rate depreciates.

In all the above studies, the seminal work was presented by Dani Rodrik (2009). This was the first study providing the framework for relating real exchange rate misalignment with economic growth. The author explored the effect of real exchange rate misalignment using the Balassa Samuelson approach for 184 countries for the period of 1950 to 2004 . He found that the higher the undervalued real exchange rate, the higher the growth with linear relation. He also found evidence empirically that undervaluation accelerates the growth of any country.

Eichengreen (2007) conceptualized the concept of economic growth and its relationship with the real exchange rate. Earlier these two were considered as the separate domain but the author focused on their interdependence. Iqbal \& Zahid (1998) discussed the determinants of economic growth. The authors took several variables including stock of physical capital, primary and secondary education, vocational training, per capita income, etc. the study revealed that stock of physical capital and primary education have a significant contribution to GDP growth. Raza et, al (2021) also concluded that greenfield investment has increased economic growth and helped to push the welfare activities of sampled countries.

\section{METHODOLOGY}

The data were obtained from the official websites of the World development indicator, IMF, Penn World Table, Pakistan Bureau of Statistics, and Ministry of Finance Pakistan. For terms of trade, the data was available on three different bases in different editions of the economic survey of Pakistan. All unit values of imports and exports were changed as per new base 1991 so that the data from editions of survey becomes uniform.

We have found the series of misalignment by first finding out the equilibrium exchange rate. In literature, there are various approaches to estimate equilibrium exchange rates. In this study, we have used the single equation approach (Baffes et al., 1999). The single equation approach assumes that some economic fundamentals including terms of trade, productivity differentials, government investment, and government spending on tradeable and non-tradeable goods, degree of trade openness, net foreign assets, and interest rate differentials determine the 
equilibrium real exchange rate. The empirical issue with using the government spending on the tradeable and non-tradeable sectors is that the data is not available anywhere or not extractable from any source. That is why it will be wise to use total government spending and let the data decide where the government spending on both of them is more. Therefore, the equation for equilibrium exchange rate is given by

$$
\begin{aligned}
\ln R E E R_{t}= & \alpha_{0}+\alpha_{1} \ln T T_{t}+\alpha_{2} \ln P D_{t}+\alpha_{3} G C F_{t}+\alpha_{4} G E X P_{t}+\alpha_{5} T N S_{t}+\alpha_{6} N F A_{t} \\
& +\alpha_{7} I R D_{t}+\varepsilon_{t} \ldots(1)
\end{aligned}
$$

Where REER is the real effective exchange rate, TT is terms of Trade, PD is productivity differentials calculated as the difference of log of per capita GDP of Pakistan and United States, GCF is the share of Gross Capital Formation representing the investment in the GDP, GEXP represents share of Government expenditures on tradeable and Non-tradeable goods in the GDP, TNS is Trade openness measured as a ratio of exports as a percentage of GDP, NFA is Net foreign Assets as a percentage of GDP and IRD is interest rate differentials calculated as the difference of real interest rates between US and Pakistan. Following the presentation of Raza et, al. (2020) The calculation of each variable with source and explanation can be seen in appendix 1:

It is worth mentioning that the empirical model has some limitation such as the REER is composed of weights of several countries whereas the gross capital formation, net foreign assets and interest rate differentials are dependent on single countries performance. Practically they should have been also calculated as per their weights of the trade with the trading countries so that the effect of other countries currency can also be incorporated. But as per almost all studies, they themselves in their original value can also be used as a good proxy for determinants of REER.

To determine the equilibrium empirically, the ARDL approach has been applied to test the possible cointegration among the variables. ARDL approach has several advantages over the traditional cointegration approach including (i) addressing the autocorrelation and endogeneity problems, (ii) unbiased estimation of long-run relationship and long-run parameters, (iii) suitability for small samples, (iv) employment of different lag lengths for different variables, (v) single equation setup and (vi) flexibility of allowing analysis with variables with mixed stationary levels at I(0) and I(1) (Harris \& Sollis, 2003; Jalil \& Ma, 2008). The descriptive statistics for the equilibrium model are in table 1 below: 
Table 1. Descriptive Statistics of Equilibrium Model Variables

\begin{tabular}{lcccccc}
\hline & Mean & Std. Dev. & Skewness & Kurtosis & Jarque-Bera & Probability \\
\hline Log of REER & 4.92 & 0.34 & 0.99 & 3.14 & 8.43 & 0.01 \\
\hline Log of Terms of Trade & 4.56 & 0.39 & -0.08 & 1.87 & 2.77 & 0.25 \\
\hline $\begin{array}{l}\text { Log of Productivity } \\
\text { differentials }\end{array}$ & 6.19 & 0.70 & -0.11 & 2.21 & 1.42 & 0.49 \\
\hline Gross Capital Formation & 0.1151 & 0.0146 & 0.0419 & 1.7060 & 3.5030 & 0.1735 \\
\hline Government Spending & 0.7612 & 0.0502 & -0.2930 & 1.9330 & 3.0875 & 0.2136 \\
\hline $\begin{array}{l}\text { Trade Openness as } \\
\text { percentage of GDP }\end{array}$ & 12.68 & 2.66 & -0.22 & 2.27 & 1.54 & 0.46 \\
\hline $\begin{array}{l}\text { Net Foreign Assets } \\
\text { Interest rate differentials }\end{array}$ & -1.885468 & 5.073509 & 0.4619 & 5.624644 & 30.42454 & 0.00
\end{tabular}

Source: Data Analysis of this Study

If the variables are non-stationary in times series analysis, then the chances of forming a spurious model are high. Therefore, it is necessary to find out whether the variables in the model are stationary or they have any unit root. Table $2 \mathrm{a}$ and Table $2 \mathrm{~b}$ show the results of the Unit Root test with the t-statistics and $\mathrm{p}$ values.

Table 1a. Stationary Test Results for Phillips Peron Test

\begin{tabular}{|c|c|c|c|c|c|c|c|c|}
\hline Phillips Peron Test & $\begin{array}{l}\text { Intercept } \\
\text { I(0) }\end{array}$ & p-Value & Trend I(0) & p-Value & $\begin{array}{l}\text { Intercept } \\
\text { I(1) }\end{array}$ & p-Value & Trend I(1) & p-Value \\
\hline Log of REER & -2.90628 & 0.051717 & -3.69377 & $0.031990 *$ & -7.73771 & $0.0000 *$ & -7.95664 & $0.0000^{*}$ \\
\hline $\begin{array}{l}\text { Log of Terms of } \\
\text { Trade }\end{array}$ & -1.34521 & 0.601361 & -3.0048 & 0.141189 & -7.7663 & $0.0000^{*}$ & -7.71921 & $0.0000 *$ \\
\hline $\begin{array}{l}\text { Log of } \\
\text { Productivity } \\
\text { differentials }\end{array}$ & -0.70055 & 0.837121 & -2.71372 & 0.235806 & -6.1709 & $0.0000^{*}$ & -6.10029 & $0.0000 *$ \\
\hline $\begin{array}{l}\text { Gross Capital } \\
\text { Formation }\end{array}$ & -2.021880 & 0.2768 & -1.991156 & 0.5915 & -5.264492 & $0.0001 *$ & -5.253609 & $0.0004 *$ \\
\hline $\begin{array}{l}\text { Government } \\
\text { Spending }\end{array}$ & -1.210277 & 0.6628 & -1.438266 & 0.8369 & -7.538847 & $0.0000^{*}$ & -7.563622 & $0.0000 *$ \\
\hline $\begin{array}{l}\text { Trade Openness as } \\
\text { percentage of GDP }\end{array}$ & -2.55139 & 0.109899 & -2.22077 & 0.46802 & -7.4894 & $0.0000^{*}$ & -10.2586 & $0.0000 *$ \\
\hline Net Foreign Assets & -2.001343 & 0.2854 & -2.101188 & 0.5322 & -6.212090 & $0.0000 *$ & -6.139237 & $0.0000 *$ \\
\hline $\begin{array}{l}\text { Interest rate } \\
\text { differentials }\end{array}$ & -3.34789 & $0.0179 *$ & -3.84654 & $0.0222 *$ & -12.3597 & $0.0000 *$ & -12.0226 & $0.0000 *$ \\
\hline
\end{tabular}

* Represents the significance at 5\% level.

Source: Data Analysis of this Study 
Table 2b. Stationary Test Results for Augmented Dickey-Fuller (ADF) Test

\begin{tabular}{|c|c|c|c|c|c|c|c|c|}
\hline $\begin{array}{l}\text { Augmented } \\
\text { Dickey-Fuller } \\
\text { Test }\end{array}$ & $\begin{array}{c}\text { Intercept } \\
\mathbf{I}(\mathbf{0})\end{array}$ & p-Value & Trend I(0) & p-Value & $\begin{array}{c}\text { Intercept } \\
\text { I(1) }\end{array}$ & p-Value & Trend I(1) & p-Value \\
\hline Log of REER & -2.92613 & $0.0495 *$ & -3.82934 & 0.02316 & -7.50172 & $0.0000 *$ & -7.61869 & $0.0000^{*}$ \\
\hline $\begin{array}{l}\text { Log of Terms of } \\
\text { Trade }\end{array}$ & -1.41395 & 0.5681 & -3.01835 & 0.137814 & -7.35842 & $0.0000 *$ & -7.29864 & $0.0000^{*}$ \\
\hline $\begin{array}{l}\text { Log of } \\
\text { Productivity } \\
\text { differentials }\end{array}$ & -0.71445 & 0.8335 & -2.50951 & 0.322503 & -6.21858 & $0.0000 *$ & -6.1564 & $0.0000^{*}$ \\
\hline $\begin{array}{l}\text { Gross Capital } \\
\text { Formation }\end{array}$ & -1.776784 & 0.3874 & -1.653179 & 0.7567 & -5.264492 & $0.0001 *$ & -5.253609 & $0.0004 *$ \\
\hline $\begin{array}{l}\text { Government } \\
\text { Spending }\end{array}$ & -1.210277 & 0.6628 & -1.247729 & 0.8887 & -7.536115 & $0.0000 *$ & -7.541991 & $0.0000^{*}$ \\
\hline $\begin{array}{l}\text { Trade Openness } \\
\text { as percentage of } \\
\text { GDP }\end{array}$ & -2.53257 & 0.1140 & -2.35586 & 0.397354 & -7.19338 & $0.0000^{*}$ & -7.38553 & $0.0000 *$ \\
\hline $\begin{array}{l}\text { Net Foreign } \\
\text { Assets }\end{array}$ & -1.880059 & 0.3387 & -1.959167 & 0.6085 & -6.243021 & $0.0000 *$ & -6.180171 & $0.0000 *$ \\
\hline $\begin{array}{l}\text { Interest rate } \\
\text { differentials }\end{array}$ & -3.36292 & $0.01740 *$ & -4.3206 & $0.0064 *$ & -7.69207 & $0.0000 *$ & -7.61479 & $0.0000 *$ \\
\hline
\end{tabular}

* Represents the significance at 5\% level.

Source: Data Analysis of this Study

Table $2 \mathrm{a}$ and $2 \mathrm{~b}$ show that the log of real effective exchange rate and interest rate differentials are stationary at level whereas the other variables except for gross capital formation (GCF) in non-stationary in both Augmented Dickey-Fuller (ADF) test or Phillips Peron (PP) test at level $\mathrm{I}(0)$ or at the first difference with intercept or with intercept and trend but stationary at I(1) both with intercept and with intercept and trend. Once the series has been tested for unit root, we estimated the equilibrium real exchange rate using equation 1 using the ARDL approach. The ARDL model used in this study is

$$
\begin{aligned}
\Delta R E E R_{t}=\varphi & +\sum \gamma_{i} \Delta T T_{t-i}+\sum \alpha_{j} \Delta P D_{t-j}+\sum \beta_{k} \Delta G E X P_{t-k}+\sum \delta_{l} \Delta G C F_{t-l} \\
& +\sum \theta_{m} \Delta T N S_{t-m}+\sum \mu_{p} \Delta N F A_{t-p}+\sum \omega_{q} \Delta I R D_{t-q}+\psi E C T_{t-1}+\varepsilon_{t} \ldots
\end{aligned}
$$

Where the variables have the same definition as defined in equation (1). Table 3 represents the summary of the model estimated.

Table 3. Long run relationship estimations for equilibrium exchange rate determination model

\begin{tabular}{lcccc}
\hline Variable & Coefficient & $\begin{array}{c}\text { Standard } \\
\text { Error }\end{array}$ & t-Statistic & Probability \\
\hline Constant & -2.197353 & 9.043152 & -0.242985 & 0.8125 \\
\hline Log of Terms of Trade & 0.066057 & 1.240090 & 0.053268 & 0.9585 \\
\hline Log of Productivity differentials & -0.572160 & 0.853510 & -0.670361 & 0.5165 \\
\hline Government Spending & 12.17649 & 3.898556 & 3.123332 & 0.0097 \\
\hline Gross Capital Formation & -19.99554 & 10.63599 & -1.879988 & 0.0868 \\
\hline Trade Openness as percentage of GDP & 0.256603 & 0.113738 & 2.256088 & 0.0454 \\
\hline Net Foreign Assets & -0.045970 & 1.880241 & -0.024449 & 0.9809 \\
\hline Interest rate differentials & -0.004011 & 0.033455 & -0.119879 & 0.9067 \\
\hline
\end{tabular}

Source: Data Analysis of this Study 
Table 3 shows that the trade openness, government share of spending on consumption, and Gross capital formation have a significant role in determining the equilibrium real exchange rate for Pakistan. The long-run bound test results for the model are shown in Table 4. The Fstatistic is 4.49 which is above the level and the first difference bounds at $10 \%$ and at $5 \%$ level which shows that there exists a long-run relationship between the variables.

Table 4. ARDL Bound Test Statistics

\begin{tabular}{ccccc}
\hline Test statistic & Value & Level of significance & At level & At first difference \\
\hline F-statistic & 4.489498 & 0.1 & 1.92 & 2.89 \\
\hline $\mathrm{k}$ & 7 & 0.05 & 2.17 & 3.21 \\
\hline & & 0.025 & 2.43 & 3.51 \\
\hline & & 0.01 & 2.73 & 3.9 \\
\hline
\end{tabular}

Source: Data Analysis of this Study

The optimal lengths of the lags were selected based on Akaike Information Criteria (AIC) as shown in figure 1 . Hence, the optimal order of ARDL is $\operatorname{ARDL}(2,3,4,4,3,3,4,4)$ which means that the optimal lag lengths of REER, government spending, gross capital formation, interest rate differentials, productivity differentials, terms of trade, net foreign assets, and trade openness are 2,3,4,4,3,3,4 and 4, respectively.

Akaike Information Criteria (top 20 models)

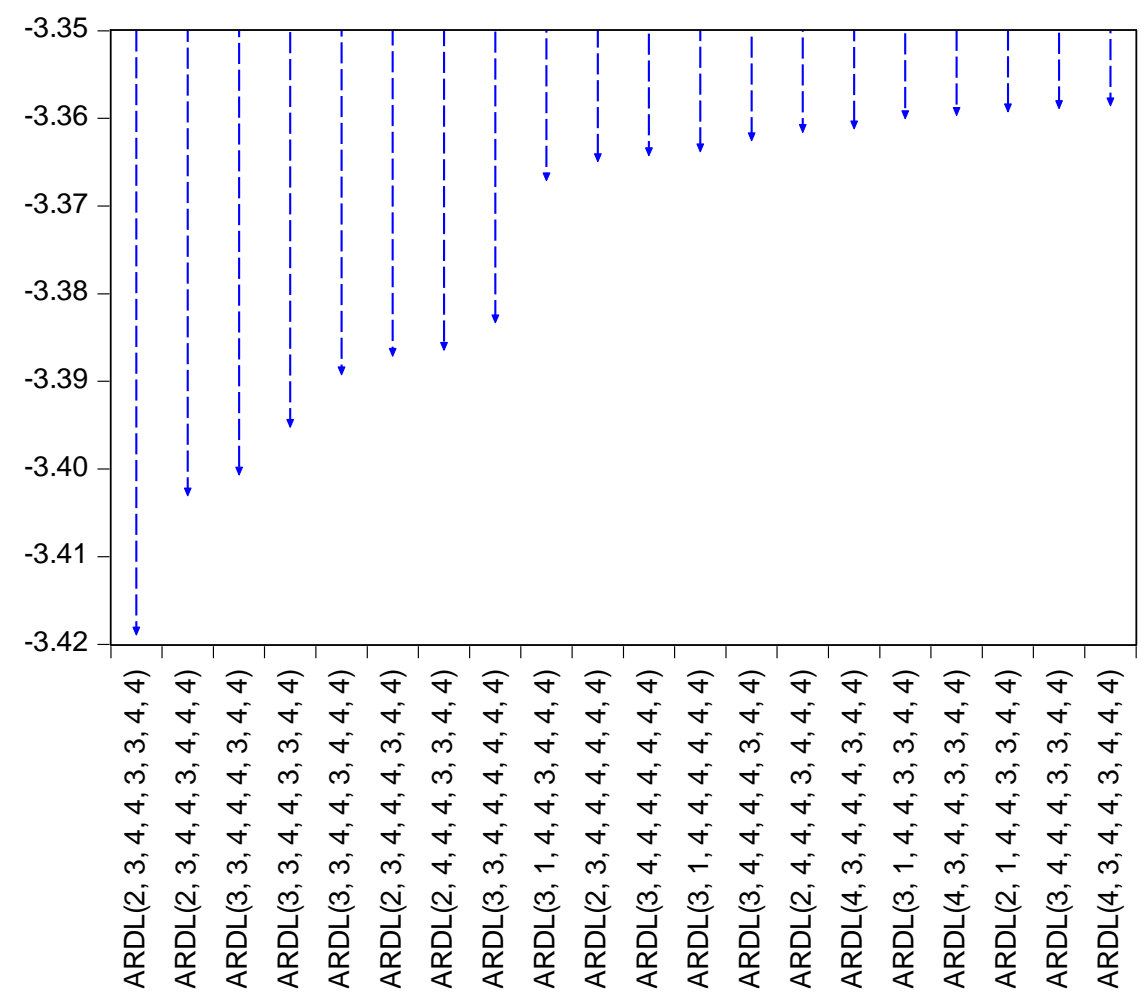

Figure 1. AIC for Top 20 Models

The value of $R^{2}=0.994781$ (adjusted $R^{2}=0.978650$ ) shows that the model is of good fit which implies that about $99 \%$ of the variation in the real effective exchange rate index is 
explained by the independent variables. In times series this is more usual to get greater $\mathrm{R}^{2}$ as the variables move in the same direction. Therefore, it is more important to consider the model's diagnostic statistics. The computed F-statistic $=61.66898$ with a probability value of 0.0000 which exhibits that the null hypothesis of regressors having zero coefficient should be rejected. Moreover, the Durbin-Watson statistic is 2.69 confirming that the regression is not spurious.

Figure 2 represents the series of Actual REER index and estimated REER index calculated by the model along with the misalignment.

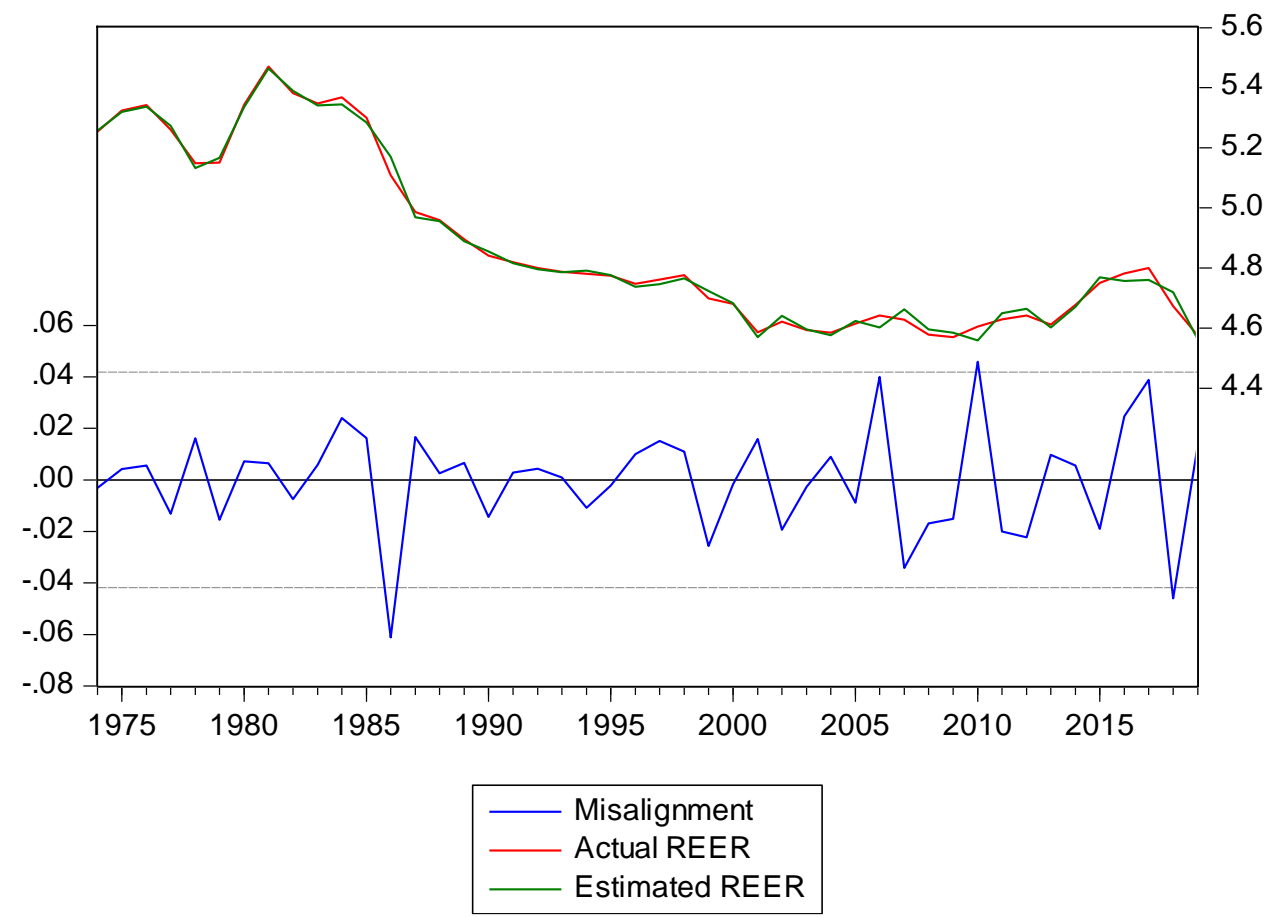

Figure 2. Actual, Estimated, and Misalignment in REER Index

After estimating the equilibrium real effective exchange rate index, we calculated the misalignment in the REER. The misalignment is the difference between the actual REER and the estimated REER. Therefore, the formula for calculating the misalignment in REER at period $t$ is given by equation 3 .

$$
m_{t}=R E E R_{t}-R \widehat{E E R}_{t}
$$

Where $m_{t}, R E E R_{t}$ and $\widehat{R E E R}_{t}$ are the misalignment in REER index, the actual REER, and the estimated REER index at time $t$. Figure 3 presents the series of misalignment calculated using equation 3. 


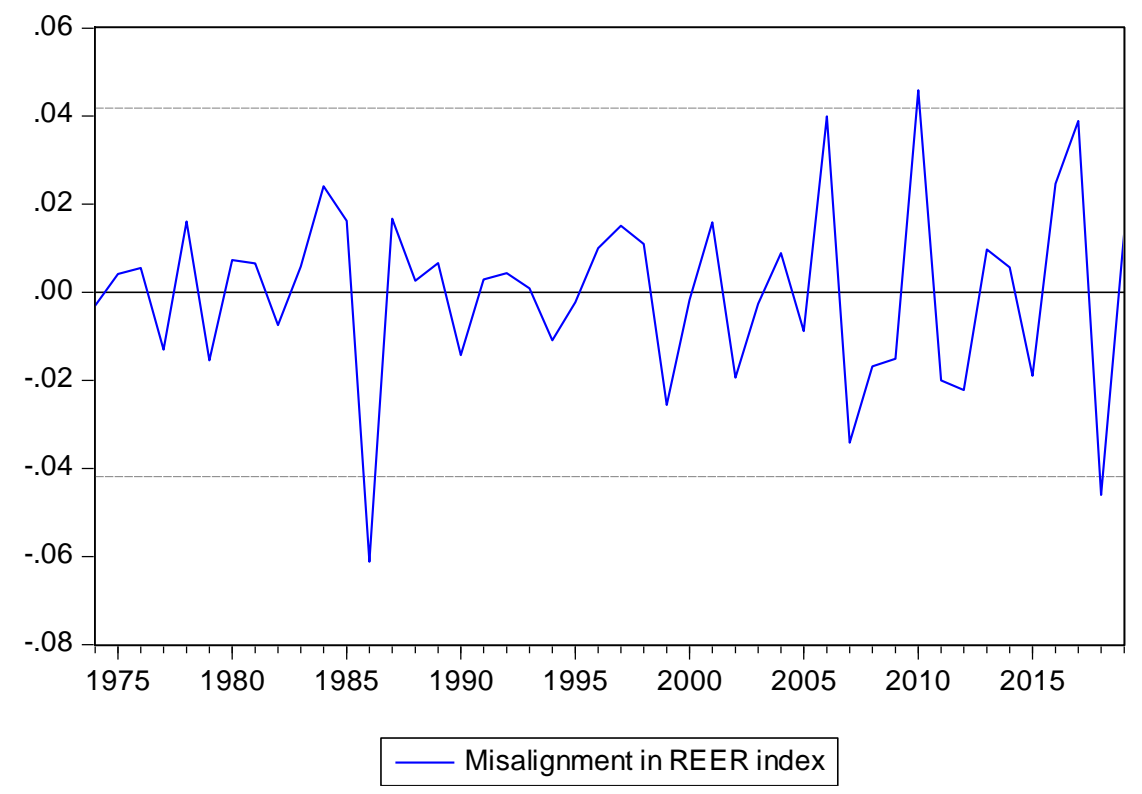

Figure 3. Series of Misalignment in REER

After finding out the series of misalignment, we will form the main model using the Barrow Growth model following the methodology of Razin \& Collins (1997) and Couharde \& Sallenave (2013). The empirical equation for growth equation can be given as

$$
g_{t}=\theta_{0}+\theta_{1} I N F_{t}+\theta_{2} G E X P_{t}+\theta_{3} G C F_{t}+\theta_{4} \ln H C_{t}+\theta_{5} T N S_{t}+\theta_{6} m_{t}+\varepsilon_{t} .
$$

Here $\mathrm{g}$ is the economic growth measured as log of real gdp per capita, INF is inflation, GEXP is share of government spending in GDP, GCF represents share of government spending on investment in GDP, $\ln H C$ represents $\log$ of the human capital index, TNS is trade openness, $m$ shows misalignment. Theoretically, it is expected that $\theta_{5} \neq 0$ as trade openness has a significant impact on economic growth. $\theta_{1}, \theta_{2}, \theta_{6}<0$ and $\theta_{4}>0$. The table 5 below represents the descriptive statistics for the growth equation variables.

Table 5. Descriptive Statistics for Growth Equation Variables

\begin{tabular}{cccccccc}
\hline & $\boldsymbol{g}$ & INF & GEXP & GCF & InHC & TNS & $\boldsymbol{m}$ \\
\hline Mean & 7.985494 & 8.868390 & 0.761215 & 0.115128 & 0.395896 & 12.68315 & $2.23 \mathrm{E}-15$ \\
\hline Std. Dev. & 0.285239 & 5.109687 & 0.050201 & 0.014577 & 0.152488 & 2.656830 & 0.020691 \\
\hline Skewness & 0.413965 & 1.554051 & -0.293004 & 0.041882 & 0.074092 & -0.217431 & -0.402993 \\
\hline Kurtosis & 2.062615 & 5.680613 & 1.932952 & 1.705997 & 1.393368 & 2.268750 & 3.919977 \\
\hline Jarque-Bera & 3.258665 & 35.79771 & 3.087493 & 3.503041 & 5.531850 & 1.538141 & 2.867277 \\
\hline Probability & 0.196060 & 0.000000 & 0.213579 & 0.173510 & 0.062918 & 0.463444 & 0.238440
\end{tabular}

Source: Data Analysis of this Study

For employing the ARDL model, it is one of the assumptions that the variables in the model should not be stationary at the second difference I(2). Some of the variables should be 
stationary at level $\mathrm{I}(0)$ and some at first difference I(1) Now we will check the stationarity of all variables included. Table 6 represents the results of stationarity tests for each variable with their t-statistic and probability values.

Table 6. Stationarity Tests for Growth Equation Variables

\begin{tabular}{|c|c|c|c|c|c|c|c|}
\hline Phillips Peron Test & $g$ & INF & GEXP & GCF & $\Delta \mathbf{H C}$ & TNS & $m$ \\
\hline Intercept $\mathrm{I}(0)$ & 0.639601 & -3.524345 & -1.210277 & -2.021880 & -2.255349 & -2.551388 & -24.21062 \\
\hline p-Value & 0.989470 & $0.01125 *$ & 0.662845 & 0.276813 & 0.190247 & 0.109899 & $0.00010 *$ \\
\hline Trend I(0) & -1.648299 & -3.558661 & -1.438266 & -1.991156 & -2.270081 & -2.220769 & -25.59867 \\
\hline p-Value & 0.758776 & $0.04396^{*}$ & 0.836882 & 0.591491 & 0.441674 & 0.468020 & $0.0000^{*}$ \\
\hline Intercept I(1) & -4.891397 & -8.181003 & -7.538847 & -5.264492 & -6.535013 & -7.489403 & -36.48593 \\
\hline p-Value & $0.00020^{*}$ & $0.0000^{*}$ & $0.0000^{*}$ & $0.0000^{*}$ & $0.0000^{*}$ & $0.0000^{*}$ & $0.00010^{*}$ \\
\hline Trend I(1) & -4.930696 & -8.000289 & -7.563622 & -5.253609 & -6.450061 & -10.25862 & -35.68365 \\
\hline $\mathrm{p}$-Value & $0.00115^{*}$ & $0.0000^{*}$ & $0.0000^{*}$ & $0.00044 *$ & $0.0000^{*}$ & $0.0000 *$ & $0.0000^{*}$ \\
\hline Augmented Dicky Fuller (ADF) test & $g$ & INF & GEXP & GCF & $\ln \mathrm{HC}$ & TNS & $m$ \\
\hline Intercept $\mathrm{I}(0)$ & 0.341113 & -3.446642 & -1.210277 & -1.776784 & -2.057386 & -2.532567 & -6.977287 \\
\hline p-Value & 0.978138 & $0.013805^{*}$ & 0.662845 & 0.387398 & 0.262342 & 0.114059 & $0.0000^{*}$ \\
\hline Trend $\mathrm{I}(0)$ & -1.586998 & -3.554219 & -1.247729 & -1.653179 & -2.074185 & -2.355860 & -6.887854 \\
\hline $\mathrm{p}$-Value & 0.783509 & $0.044408^{*}$ & 0.888663 & 0.756709 & 0.546849 & 0.397354 & $0.0000^{*}$ \\
\hline Intercept I(1) & -4.871534 & -6.861850 & -7.536115 & -5.264492 & -6.535013 & -7.193376 & -5.822544 \\
\hline p-Value & $0.00022 *$ & $0.0000^{*}$ & $0.0000^{*}$ & $6.18 \mathrm{E}-05$ & $0.0000^{*}$ & $1.18 \mathrm{E}-07$ & $0.0000^{*}$ \\
\hline Trend I(1) & -4.896897 & -6.792864 & -7.541991 & -5.253609 & -6.450061 & -7.385529 & -5.800295 \\
\hline p-Value & $0.00127 *$ & $0.0000 *$ & $0.0000 *$ & 0.000438 & $0.0000^{*}$ & $4.02 \mathrm{E}-07$ & $0.00010^{*}$ \\
\hline
\end{tabular}

* Represents the significance at $5 \%$ level.

Source: Data Analysis of this Study

It can be seen in table 6 that $\mathrm{g}$, GEXP, GCF, lnHC, TNS are stationary at $1^{\text {st }}$ difference $\mathrm{I}(1)$ in all criteria whereas the remaining variables are stationary at level. Therefore, the data is suitable for use of ARDL. The ARDL model used in this study is:

$$
\begin{gathered}
\Delta g_{t}=\varphi+\sum \gamma_{i} \Delta I N F_{t-i}+\sum \alpha_{j} \Delta G E X P_{t-j}+\sum \beta_{k} \Delta G C F_{t-k}+\sum \delta_{l} \Delta H C_{t-l}+\sum \theta_{m} \Delta T N S_{t-m} \\
+\sum \vartheta_{n} \Delta m_{t-n}+\psi E C T_{t-1}+\varepsilon_{t} \ldots(3)
\end{gathered}
$$

\section{Optimal Lag Lengths}

The optimal lengths of the lags were selected based on Akaike Information Criteria (AIC) as shown in Figure 4. Hence, the optimal order of ARDL is ARDL $(4,3,3,4,2,1,3)$ which means that the optimal lag lengths of growth, inflation, government spending, gross capital formation, change in the human capital index, misalignment are 4, 2, 0, 4, 1, 4, and 1 respectively. 
Akaike Information Criteria (top 20 models)

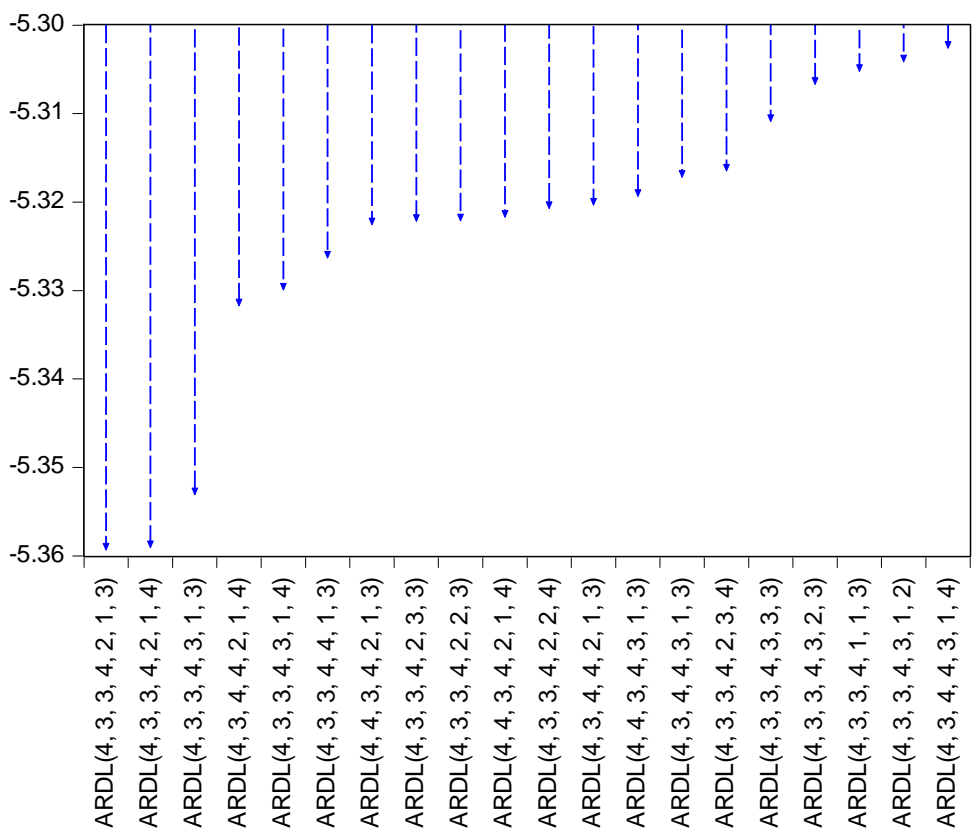

Figure 4. Akaike Information Criteria for Top 20 models

\section{Bound Test Result}

After the diagnostics of the model, we moved to the cointegration bound test. The related F statistic $=5.35$. Since the variables are the mix of the level and first difference, the availability of the exact critical values for the F-test is not possible as the variables are a mix of at level and the first difference. Table 7 represents the critical bounds at $1 \%, 5 \%$, and $10 \%$ for both large and small samples.

Table 7. ARDL Bound Test for Cointegration

\begin{tabular}{lcccc}
\hline & \multicolumn{2}{c}{ Pesaran et al. (2001) } & \multicolumn{2}{c}{ (Narayan, 2004) } \\
\hline At 1\% level of significance & 2.88 & 3.99 & 3.54 & 4.931 \\
\hline At 5\% level of significance & 2.27 & 3.28 & 2.591 & 3.766 \\
\hline At 10\% level of significance & 1.99 & 2.94 & 2.188 & 3.254 \\
\hline Calculated F-statistic & \multicolumn{2}{c}{5.358884} & \multicolumn{2}{c}{5.358884}
\end{tabular}

Source: Data Analysis of this Study

\section{Long Run Coefficients}

The long-run coefficients of the independent variables can be seen in Table 8. As theoretically expected, the signs of INF, GEXP and MISALG i.e., inflation, government spending and misalignment in real exchange rate should be negative but they have the opposite sign. The sign and magnitude of GEXP can be ignored as it is not significant at 5\% level. The human capital (LnHC) has sign as theoretically expected and significant. However, the trade openness is insignificant. Table 3-8 also confirms a long-run significant relationship between real exchange rate misalignment and economic growth. 
Table 8. Long Run Coefficients

\begin{tabular}{ccccc}
\hline Variable & Coefficient & Std. Error & t-Statistic & Prob. \\
\hline INFL & 0.009384 & 0.003940 & 2.381721 & 0.0300 \\
\hline GEXP & 0.944723 & 0.492987 & 1.916324 & 0.0734 \\
\hline GCF & 2.155331 & 1.633134 & 1.319751 & 0.2055 \\
\hline LNHC & 1.731321 & 0.082885 & 20.88826 & 0.0000 \\
\hline TNS & 0.001830 & 0.009418 & 0.194307 & 0.8484 \\
\hline MIS & 6.625074 & 1.509183 & 4.389840 & 0.0005 \\
\hline C & 6.499452 & 0.529668 & 12.27080 & 0.0000
\end{tabular}

Source: Data Analysis of this Study

\section{Error Correction Form}

The error correction form signifies adjustment speed for a variable to achieve its balance. The ECT form of the model is given in equation (3). Table 9 shows the results of the error correction form of the growth model. The ECT coefficient (Cointeq(-1)) has a negative sign with significance at $10 \%, 5 \%$, and $1 \%$. This confirms a long-run relationship between the variables regressed and the economic growth.

$$
\begin{gathered}
\Delta g_{t}=\varphi+\sum \gamma_{i} \Delta I N F_{t-i}+\sum \alpha_{j} \Delta G E X P_{t-j}+\sum \beta_{k} \Delta G C F_{t-k}+\sum \delta_{l} \Delta H C_{t-l}+\sum \theta_{m} \Delta T N S_{t-m} \\
+\sum \vartheta_{n} \Delta m_{t-n}+\sum \mu_{p} \Delta m_{t-p}^{2}+\psi E C T_{t-1}+\varepsilon_{t} \ldots(3)
\end{gathered}
$$

\begin{tabular}{|c|c|c|c|c|}
\hline Variable & Coefficient & Std. Error & t-Statistic & Prob. \\
\hline$\Delta g_{t-1}$ & -0.483113 & 0.128178 & -3.769088 & 0.0017 \\
\hline$\Delta g_{t-2}$ & -0.867555 & 0.138560 & -6.261233 & 0.0000 \\
\hline$\overline{\Delta g_{t-3}}$ & -0.705247 & 0.171957 & -4.101291 & 0.0008 \\
\hline$\overline{\Delta G E X P_{t}}$ & -0.002725 & 0.125673 & -0.021685 & 0.9830 \\
\hline$\overline{\Delta G E X P_{t-1}}$ & -1.082749 & 0.152933 & -7.079885 & 0.0000 \\
\hline$\Delta G E X P_{t-2}$ & -0.814661 & 0.156577 & -5.202930 & 0.0001 \\
\hline$\Delta G C F_{t}$ & 0.866503 & 0.334589 & 2.589756 & 0.0197 \\
\hline$\Delta G C F_{t-1}$ & -1.351296 & 0.333700 & -4.049429 & 0.0009 \\
\hline$\Delta G C F_{t-2}$ & -1.301782 & 0.367387 & -3.543350 & 0.0027 \\
\hline$\overline{\Delta G C F_{t-3}}$ & -1.085070 & 0.371026 & -2.924510 & 0.0099 \\
\hline$\overline{\Delta T N S_{t}}$ & 0.008929 & 0.002219 & 4.024141 & 0.0010 \\
\hline$\Delta m_{t}$ & -0.913478 & 0.281217 & -3.248310 & 0.0040 \\
\hline$\Delta m_{t-1}$ & -1.271278 & 0.231676 & -5.487316 & 0.0000 \\
\hline$\Delta m_{t-2}$ & -0.411268 & 0.132789 & -3.097158 & 0.0069 \\
\hline$\Delta \ln H C_{t}$ & -3.128345 & 0.436707 & -7.163480 & 0.0000 \\
\hline$\overline{\Delta l n H C_{t-1}}$ & -1.298159 & 0.656282 & -1.978050 & 0.0654 \\
\hline$\overline{\Delta I N F_{t}}$ & 0.003550 & 0.000819 & 4.335398 & 0.0005 \\
\hline$\Delta I N F_{t-1}$ & 0.004696 & 0.000700 & 6.711623 & 0.0000 \\
\hline$\Delta I N F_{t-2}$ & 0.002199 & 0.000761 & 2.890935 & 0.0106 \\
\hline CointEq(-1)* & -0.398165 & 0.050720 & -7.850297 & 0.0000 \\
\hline
\end{tabular}

Table 9. Error Correction Form of the Model

Source: Data Analysis of this Study 


\section{Model Diagnostics}

The value of $R^{2}=0.998854$ confirms the goodness of fit of the model. The adjusted $R^{2}=$ 0.996991 signifying that $99 \%$ of the variation in economic growth proxies can be explained by the variables present in the model. The Durbin Watson statistics is 2.1256 which is closer to 2 signifying the regression is not spurious. Moreover, the F statistics is 536.054816 (p-value $=0.00000$ ) which is significant at $10 \%, 5 \%$ and even at $1 \%$. The statistics of serial correlation, the test of normality, and heteroscedasticity for residuals are summarized in table 7.

Table 10. Residual Diagnostics of the Model

\begin{tabular}{lcc}
\hline Test & $\chi^{\mathbf{2}}$ & p-value \\
\hline Breusch-Godfrey Serial Correlation LM Test & 5.402147 & 0.0671 \\
\hline Breusch-Pagan-Godfrey Heteroscedasticity Test & 27.15255 & 0.4014 \\
\hline Jarque-Berra test & 1238717 & 0.5383 \\
\hline Source: Data Analysis of this Study & &
\end{tabular}

Table 10 demonstrates that the model qualifies normality, serial correlation, and heteroscedasticity in residuals test.

\section{Stability of the Model}

The robustness of the results was checked using structural stability tests. The researchers tested the stability on the parameters with two approaches include cumulative sum of recursive residuals (CUSUM) and cumulative sum of squares of residuals (CUSUMSQ). Figure 5 and figure 6 represent the results of CUSUM and CUSUMSQ respectively. The boundaries of the dotted line show $5 \%$ significance lines for residuals and the sum of their squares. Both CUSUM and CUSUMSQ plots are within the boundaries of 5\% whereas the data points of 2005 to 2009 in CUSUMSQ are below 10\% (5\% and 6\% respectively). Hence, the researchers found no significant systematic change in the coefficients over the period studied.

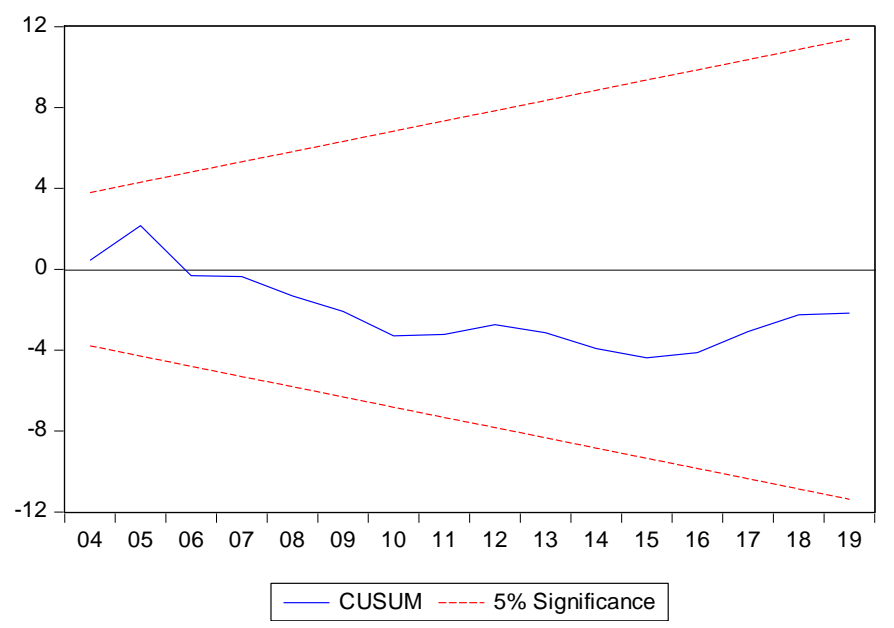

Figure 5. Cumulative Sums of Recursive Residuals (CUSUM) Plot 


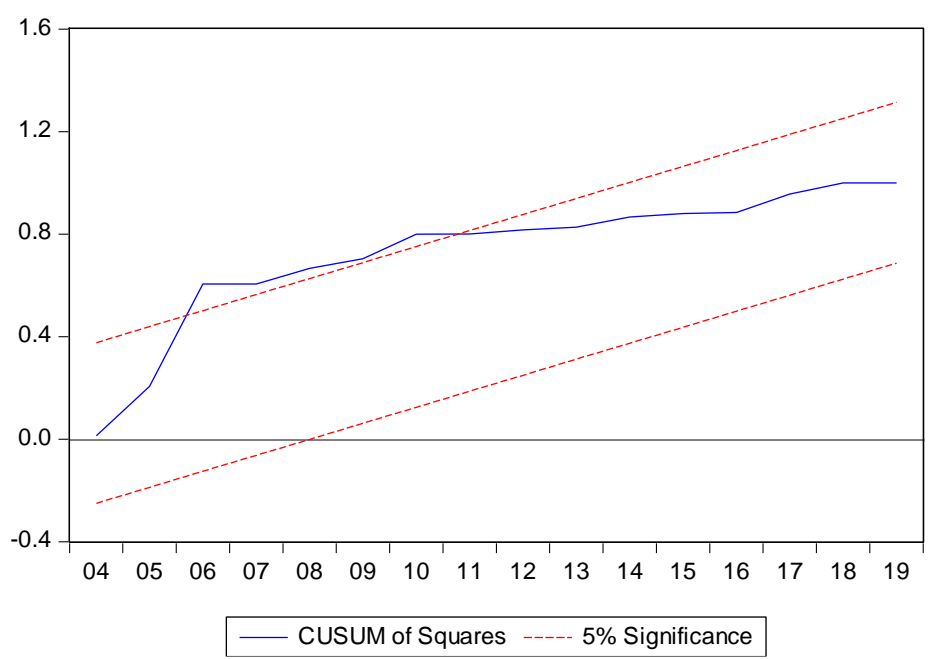

Figure 4. Cumulative Sum of Recursive Residuals of Squares (CUSUMSQ) Plot

\section{Granger Causality Test}

After finding out the long-run relationship among the variables, the next step is to find the Granger Causality test following (Toda-Yamamoto, 1995) method. The causality may be unidirectional or bidirectional Table 11 shows the results of the Granger causality test.

Table 11. Granger Causality Statistics

\begin{tabular}{|c|c|c|c|c|c|c|c|c|}
\hline $\begin{array}{l}\text { Variable / } \\
\text { Direction }\end{array}$ & GROWTH & GEXP & INFL & GCF & TNS & MISALG & LNHC & Outcome \\
\hline GROWTH & - & $\begin{array}{l}0.60843 \\
(0.5488)\end{array}$ & $\begin{array}{l}1.08036 \\
(0.3485)\end{array}$ & $\begin{array}{l}0.00943 \\
(0.9906)\end{array}$ & $\begin{array}{l}0.96290 \\
(0.3899)\end{array}$ & $\begin{array}{l}0.05771 \\
(0.9440)\end{array}$ & $\begin{array}{l}3.17974 \\
(0.0515)\end{array}$ & $\begin{array}{c}\text { Growth } \rightarrow \text { Human } \\
\text { Capital }\end{array}$ \\
\hline GEXP & $\begin{array}{l}0.56053 \\
(0.5750)\end{array}$ & - & $\begin{array}{l}0.75958 \\
(0.4740)\end{array}$ & $\begin{array}{c}3.39422 \\
(0.0428)^{*}\end{array}$ & $\begin{array}{c}6.16132 \\
(0.0044)^{*}\end{array}$ & $\begin{array}{l}0.30995 \\
(0.7353)\end{array}$ & $\begin{array}{l}1.33312 \\
(0.2743)\end{array}$ & $\begin{array}{c}\text { Government consumption } \\
\rightarrow \text { government investment } \\
\text { Government consumption } \\
\rightarrow \text { Trade openness }\end{array}$ \\
\hline INFL & $\begin{array}{l}1.05185 \\
(0.3581)\end{array}$ & $\begin{array}{l}0.44233 \\
(0.6454)\end{array}$ & - & $\begin{array}{l}0.51496 \\
(0.6012)\end{array}$ & $\begin{array}{l}0.77236 \\
(0.4681)\end{array}$ & $\begin{array}{l}0.23899 \\
(0.7886)\end{array}$ & $\begin{array}{l}0.56099 \\
(0.5747)\end{array}$ & \\
\hline GCF & $\begin{array}{l}1.89128 \\
(0.1632)\end{array}$ & $\begin{array}{l}3.94192 \\
(0.027)^{*}\end{array}$ & $\begin{array}{l}0.24311 \\
(0.7853)\end{array}$ & - & $\begin{array}{l}0.02148 \\
(0.9788)\end{array}$ & $\begin{array}{l}0.09247 \\
(0.9119)\end{array}$ & $\begin{array}{l}0.73068 \\
(0.4875)\end{array}$ & $\begin{array}{c}\text { Government spending on } \\
\text { investment } \\
\rightarrow \text { Government } \\
\text { consumption }\end{array}$ \\
\hline TNS & $\begin{array}{l}0.62681 \\
(0.5391)\end{array}$ & $\begin{array}{l}1.16307 \\
(0.3222)\end{array}$ & $\begin{array}{l}2.28979 \\
(0.1132)\end{array}$ & $\begin{array}{l}5.95515 \\
(0.0052)\end{array}$ & - & $\begin{array}{l}0.04866 \\
(0.9526)\end{array}$ & $\begin{array}{l}0.49325 \\
(0.6140)\end{array}$ & \\
\hline MISALG & $\begin{array}{l}1.01743 \\
(0.3709)\end{array}$ & $\begin{array}{l}1.03126 \\
(0.3661)\end{array}$ & $\begin{array}{l}1.21430 \\
(0.3079)\end{array}$ & $\begin{array}{l}0.72142 \\
(0.4924)\end{array}$ & $\begin{array}{l}0.56519 \\
(0.5728)\end{array}$ & - & $\begin{array}{l}0.58194 \\
(0.5636)\end{array}$ & \\
\hline LNHC & $\begin{array}{c}4.61772 \\
(0.0153)^{*}\end{array}$ & $\begin{array}{l}1.06933 \\
(0.3522) \\
\end{array}$ & $\begin{array}{l}1.05089 \\
(0.3582) \\
\end{array}$ & $\begin{array}{l}1.83849 \\
(0.1713) \\
\end{array}$ & $\begin{array}{l}1.39395 \\
(0.2588) \\
\end{array}$ & $\begin{array}{l}0.09472 \\
(0.9098)\end{array}$ & - & $\begin{array}{l}\text { Human Capital } \\
\rightarrow \text { Growth }\end{array}$ \\
\hline
\end{tabular}

Source: Data Analysis of this Study

Table 11 shows that the human capital and growth have bidirectional granger causality as well as government consumption and investment share in GDP also have bidirectional granger causality. The government share of consumption spending also granger causes the trade openness. 


\section{CONCLUSION AND RECOMMENDATIONS}

This paper examines the nexus between economic growth and the real exchange rate misalignment in the case of Pakistan for 1970 - 2020. The study accounts for the cointegration, long-run and short-run dynamics, and causal relationships between the growth and misalignment. We applied Auto-Regressive Distributed Logs (ARDL) bounds testing method to examine the cointegration, Error Correction Method (ECM) for the long run and short-run dynamics, and Toda \& Yamamoto (1995) procedure for Granger causality between the fundamental variables.

The study confirms the short-run and long-run cointegration between the misalignment of REER and economic growth of Pakistan by the ARDL bound test as well as additional crosschecking. The misalignment impacts economic growth positively and significantly in the longrun and negatively in the short run. All the diagnostical procedure validates the tests showing the stability of the model. The Granger causality showed the non-existence causality between the misalignments of the real exchange rate. The results are similar to some of the studies including Missio et al. (2015), Vieira \& MacDonald (2012) and contrasting with (Dani Rodrik, 2009; Mamun et al., 2020; Tarawalie, 2011; Tarawalie, 2021; Tsen Wong, 2013).

\section{PRACTICAL IMPLICATIONS AND GENERALIZABILITY}

The results suggest that the misalignment in the real exchange enhances economic growth. Thus, the policymakers should consider enhancing the misalignment to achieve maximum economic growth. The tools for controlling the real exchange rate misalignment found by this study are gross capital formation, government spending, and trade openness. In long run, the gross capital formation and has a negative impact of equilibrium RER determination whereas the equilibrium RER is positively affected by trade openness and government spending. Hence, the policymakers should make policies to control the gross capital formation and spending and trade liberation policies for highest economic growth.

In addition to policymakers, the study can also be useful for the consumer sector. As Pakistan's consumer products imports are more than exports, The prices of consumer goods can be affected by misalignment of the real exchange rate. The demand and supply of consumer goods are directly affected by the exchange rate therefore, a stable and effective exchange rate policy can help achieve sustainable progress of the consumer sector. The results can also be generalized for countries with the same economic features of developing and emerging markets and economies. 


\section{REFERENCES}

Ahmed, H. (2009). Capital Flows and Real Exchange Rate Overvaluation - A Chronic Ailment: Evidence from Pakistan. THE LAHORE JOURNAL OF ECONOMICS, 14(Special Edition), 51-86. https://doi.org/10.35536/lje.2009.v14.isp.a4

Baffes, J., O’Connell, S. A., \& Elbadawi, I. A. (1999). Single-Equation Estimation of the Equilibrium Real Exchange Rate. Policy Research Working Papers. https://doi.org/10.1596/1813-9450-1800

Banerjee, K., \& Goyal, A. (2021). Behavioural equilibrium real exchange rates and misalignments: Evidence from large emerging markets. Economic Analysis and Policy, 70, 414-436. https://doi.org/10.1016/j.eap.2021.03.004

Berg, A., \& Miao, Y. (2010). The Real Exchange Rate and Growth Revisited: The Washington Consensus Strikes Back? IMF Working Papers, 10(58), 1. https://doi.org/10.5089/9781451963755.001

Beveridge, S., \& Nelson, C. R. (1981). A new approach to decomposition of economic time series into permanent and transitory components with particular attention to measurement of the 'business cycle.' Journal of Monetary Economics, 7(2), 151-174. https://doi.org/10.1016/0304-3932(81)90040-4

Clarida, R., \& Gali, J. (1994). Sources of real exchange-rate fluctuations: How important are nominal shocks? Carnegie-Rochester Conference Series on Public Policy, 41, 1-56. https://doi.org/10.1016/0167-2231(94)00012-3

Clark, P. B., Symansky, S. A., Bayoumi, T., \& Taylor, M. P. (1994). Robustness of Equilibrium Exchange Rate Calculations to Alternative Assumptions and Methodologies. IMF Working Papers, 94(17), 1. https://doi.org/10.5089/9781451843477.001

Couharde, C., \& Sallenave, A. (2013). How do currency misalignments' threshold affect economic growth? Journal of Macroeconomics, 36, 106-120. https://doi.org/10.1016/j.jmacro.2012.11.002

Dani Rodrik. (2009). The Real Exchange Rate and Economic Growth. Brookings Papers on Economic Activity, 2008(2), 365-412. https://doi.org/10.1353/eca.0.0020

Detken, C., Dieppe, A., Henry, J., Smets, F., \& Marin, C. (2002). Determinants of the Effective Real Exchange Rate of the Synthetic Euro: Alternative Methodological Approaches. Australian Economic Papers, 41(4), 404-436. https://doi.org/10.1111/1467-8454.00173

Edwards, S. (1989). EXCHANGE RATE MISALIGNMENT IN DEVELOPING COUNTRIES. The World Bank Research Observer, 4(1), 3-21. https://doi.org/10.1093/wbro/4.1.3

Eichengreen, B. (2007). THE REAL EXCHANGE RATE AND ECONOMIC GROWTH. Social and Economic Studies, 56(4), 7-20. https://www.jstor.org/stable/27866525 
Gonzalo, J., \& Granger, C. (1995). Estimation of Common Long-Memory Components in Cointegrated Systems. Journal of Business \& Economic Statistics, 13(1), 27-35. https://doi.org/10.1080/07350015.1995.10524576

Harris, R., \& Sollis, R. (2003). Applied Time Series Modelling and Forecasting. Wiley.

Hoekman, B. (2021). DIGITALIZATION, INTERNATIONAL TRADE, AND ARAB ECONOMIES: EXTERNAL POLICY IMPLICATIONS (Issue 1484). Economic Research Forum Working Papers.

Iqbal, Z., \& Zahid, G. M. (1998). Macroeconomic Determinants of Economic Growth in Pakistan. The Pakistan Development Review, 37(2), 125-148. https://doi.org/10.30541/v37i2pp.125-148

Jalil, A., \& Ma, Y. (2008). Financial development and economic growth: Time series evidence from pakistan and china. Journal of Economic Cooperation, 29(2), 29-68.

List, F. (2017). The National System Of Political Economy. CreateSpace Independent Publishing Platform.

MacDonald, R. R. (2000). Concepts to calculate equilibrium exchange rates: An overview. SSRN Electronic Journal. https://doi.org/10.2139/ssrn.2785109

Maeso-Fernandez, F., Osbat, C., \& Schnatz, B. (2002). Determinants of the euro real effective exchange rate: A BEER/PEER approach. Australian Economic Papers, 41(4), 437-461. https://doi.org/10.1111/1467-8454.00174

Mahraddika, W. (2020). Real exchange rate misalignments in developing countries: The role of exchange rate flexibility and capital account openness. International Economics, 163, 1-24. https://doi.org/10.1016/j.inteco.2020.04.004

Mamun, A. H., Bal, H., \& Basher, S. (2020). Does currency misalignment matter for economic growth? - evidence from turkey. EuroMed Journal of Business, 16(4), 471-486. https://doi.org/10.1108/emjb-08-2019-0101

Missio, F. J., Jayme, F. G., Britto, G., \& Luis Oreiro, J. (2015). Real Exchange Rate and Economic Growth: New Empirical Evidence. Metroeconomica, 66(4), 686-714. https://doi.org/10.1111/meca.12087

Narayan, P. K. (2004). Reformulating Critical Values for the Bounds F-statistics Approach to Cointegration: An Application to the Tourism Demand Model for Fiji . Department of Economics, 02.

Raza, A., Azam, M. K, \& Tariq, M. (2020) "A Panel Data Investigation of Greenfield Investment on the Welfare of African Developing Countries." International Review of Social Sciences, 8(8), 41-57

Raza, A., Iqbal, M., \& Hussian, N. (2021). Is Greenfield Investment Greener for the Welfare of Lower-Middle Income Countries? Market based Empirical Analysis with GMM 
Approach. Journal of Marketing Strategies, 3(3), 194 - 206.

https://doi.org/10.52633/jms.v3i3.111

Razin, O., \& Collins, S. M. (1997). Real exchange rate misalignments and growth (Issue 6174). National Bureau of Economic Research. https://doi.org/10.3386/w6174

Siregar, R. Y. (2011). The Concepts of Equilibrium Exchange Rate: A Survey of Literature. The Southeast Asian Central Banks (SEACEN) Research and Training Centre Kuala Lumpur, Malaysia. https://mpra.ub.uni-muenchen.de/id/eprint/28987

Stein, J. L. (1994). The natural real exchange rate of the US dollar and determinants of capital flows. Estimating Equilibrium Exchange Rates, 133-175.

Stock, J. H., \& Watson, M. W. (1988). Testing for Common Trends. Journal of the American Statistical Association, 83(404), 1097-1107. https://doi.org/10.1080/01621459.1988.10478707

Tarawalie, A. (2011). Real exchange rate behaviour and economic growth: evidence from Sierra Leone. South African Journal of Economic and Management Sciences, 13(1), 825. https://doi.org/10.4102/sajems.v13i1.195

Tarawalie, A. B. (2021). Equilibrium Real Exchange Rate and Misalignment: The Sierra Leone Perspective. Applied Economics and Finance, 8(3), 41. https://doi.org/10.11114/aef.v8i3.5267

Toda, H. Y., \& Yamamoto, T. (1995). Statistical inference in vector autoregressions with possibly integrated processes. Journal of Econometrics, 66(1-2), 225-250. https://doi.org/10.1016/0304-4076(94)01616-8

Tsen Wong, H. (2013). Real exchange rate misalignment and economic growth in Malaysia. Journal of Economic Studies, 40(3), 298-313. https://doi.org/10.1108/01443581311283934

Tyers, R., Golley, J., Yongxiang, B., \& Bain, I. (2008). China's economic growth and its real exchange rate. China Economic Journal, 1(2), 123-145. https://doi.org/10.1080/17538960802076455

Vieira, F. V., \& MacDonald, R. (2012). A panel data investigation of real exchange rate misalignment and growth. Estudos Econômicos (São Paulo), 42(3), 433-456. https://doi.org/10.1590/s0101-41612012000300001

Williamson, J. (1985). More on Choosing the Right Rules for Exchange-rate Management. The World Economy, 8(1), 81-83. https://doi.org/10.1111/j.1467-9701.1985.tb00379.x 


\section{APPENDIX}

\section{List of Variables}

\begin{tabular}{|c|c|c|c|c|}
\hline $\begin{array}{l}\text { Symbol used } \\
\text { in the study }\end{array}$ & Variable & Explanation & $\begin{array}{c}\text { Calculation / } \\
\text { Unit }\end{array}$ & Source \\
\hline $\ln R E E R_{t}$ & $\begin{array}{c}\text { Natural log of } \\
\text { Real effective } \\
\text { exchange rate } \\
\text { at year } t\end{array}$ & $\begin{array}{l}\text { Real Effective Exchange } \\
\text { rate (REER) index. The } \\
\text { REER is the weighted } \\
\text { average of real exchange } \\
\text { rates of different } \\
\text { currencies. It takes into } \\
\text { account the trading } \\
\text { currencies and their price } \\
\text { level along with the trade } \\
\text { weights }\end{array}$ & $\begin{array}{c}\text { Index out of } \\
100 . \\
\text { Transformed } \\
\text { each set of data } \\
\text { to } 2010 \text { as base } \\
\text { year. }\end{array}$ & $\begin{array}{c}\text { World } \\
\text { Development } \\
\text { Indicator, Pakistan } \\
\text { Bureau of } \\
\text { Statistics, State } \\
\text { Bank of Pakistan, } \\
\text { Ministry of } \\
\text { Finance Pakistan }\end{array}$ \\
\hline $\ln T T_{t}$ & $\begin{array}{c}\text { Natural log of } \\
\text { terms of trade } \\
\text { at year } t\end{array}$ & $\begin{array}{l}\text { the ratio of unit value of } \\
\text { exports index to the unit } \\
\text { value of import index }\end{array}$ & $\begin{array}{c}\text { Index out of } \\
100 . \\
\text { Transformed } \\
\text { each set of data } \\
\text { to } 1991 \text { as base } \\
\text { year. }\end{array}$ & $\begin{array}{l}\text { Pakistan Bureau of } \\
\text { Statistics and } \\
\text { Ministry of } \\
\text { Finance Pakistan }\end{array}$ \\
\hline $\ln P D_{t}$ & $\begin{array}{c}\text { Natural } \log \text { of } \\
\text { productivity } \\
\text { differential at } \\
\text { year } t\end{array}$ & $\begin{array}{l}\text { the per capita GDP } \\
\text { difference between } \\
\text { Pakistan and the US }\end{array}$ & USD & IMF data bank \\
\hline$G C F_{t}$ & $\begin{array}{c}\text { Gross capital } \\
\text { formation at } \\
\text { year } \mathrm{t}\end{array}$ & $\begin{array}{l}\text { government investment } \\
\text { spending as a percentage } \\
\text { of GDP }\end{array}$ & $\%$ & $\begin{array}{c}\text { Penn World Table } \\
10.0\end{array}$ \\
\hline$E X P_{t}$ & $\begin{array}{l}\text { Government } \\
\text { share of } \\
\text { consumption } \\
\text { spending in } \\
\text { GDP at year } \mathrm{t}\end{array}$ & $\begin{array}{c}\text { government expenditures } \\
\text { on tradeable and non- } \\
\text { tradeable goods as a } \\
\text { percentage of GDP }\end{array}$ & $\%$ & $\begin{array}{c}\text { Penn World Table } \\
10.0\end{array}$ \\
\hline$T N S_{t}$ & $\begin{array}{l}\text { Trade } \\
\text { openness at } \\
\text { year } t\end{array}$ & $\begin{array}{l}\text { degree of trade openness. } \\
\text { Trade openness is } \\
\text { measured as a ratio of } \\
\text { exports as a percentage of } \\
\text { GDP }\end{array}$ & $\%$ & $\begin{array}{l}\text { World } \\
\text { Development } \\
\text { Indicator }\end{array}$ \\
\hline$N F A_{t}$ & $\begin{array}{c}\text { Net foreign } \\
\text { assets as a } \\
\text { percentage of } \\
\text { GDP at year } \mathrm{t}\end{array}$ & $\begin{array}{l}\text { Net foreign Assets as a } \\
\text { percentage of GDP }\end{array}$ & $\%$ & $\begin{array}{c}\text { Penn World Table } \\
\text { 10.0, World } \\
\text { Development } \\
\text { Indicator } \\
\end{array}$ \\
\hline$I R D_{t}$ & $\begin{array}{l}\text { Interest rate } \\
\text { differentials } \\
\text { at year t }\end{array}$ & $\begin{array}{l}\text { interest rate differentials } \\
\text { calculated as the } \\
\text { difference of real interest } \\
\text { rates between US and } \\
\text { Pakistan }\end{array}$ & $\%$ & $\begin{array}{c}\text { Ministry of } \\
\text { Finance Pakistan, } \\
\text { IMF Data bank }\end{array}$ \\
\hline
\end{tabular}




\begin{tabular}{|c|c|c|c|c|}
\hline$m_{t}$ & $\begin{array}{c}\text { Misalignment } \\
\text { of REER } \\
\text { index at year } \mathrm{t}\end{array}$ & $\begin{array}{c}\text { Difference between the } \\
\text { actual REER and } \\
\text { estimated REER from the } \\
\text { model }\end{array}$ & $\begin{array}{c}\text { Index with base } \\
2010\end{array}$ & $\begin{array}{c}\text { Author's own } \\
\text { calculation }\end{array}$ \\
\hline$g_{t}$ & $\begin{array}{c}\text { Economic } \\
\text { growth at year } \\
\mathrm{t}\end{array}$ & $\begin{array}{c}\text { Calculated as log } \\
\text { difference of real GDP per } \\
\text { capital. }\end{array}$ & $\%$ & $\begin{array}{c}\text { World } \\
\text { Development } \\
\text { Indicator }\end{array}$ \\
\hline$I N F_{t}$ & $\begin{array}{c}\text { Inflation at } \\
\text { year t }\end{array}$ & $\begin{array}{c}\text { Calculated as log } \\
\text { difference of current and } \\
\text { previous year Consumer } \\
\text { Price Index (CPI) }\end{array}$ & $\%$ & $\begin{array}{c}\text { World } \\
\text { Development } \\
\text { Indicator }\end{array}$ \\
\hline $\ln H C_{t}$ & $\begin{array}{c}\text { Natural log of } \\
\text { Human } \\
\text { capital index } \\
\text { at year t }\end{array}$ & $\begin{array}{c}\text { Human capital index, } \\
\text { based on years of } \\
\text { schooling and returns to } \\
\text { education. }\end{array}$ & $\begin{array}{c}\text { Index out of } \\
100\end{array}$ & $\begin{array}{c}\text { Penn World Table } \\
10.0\end{array}$ \\
\hline
\end{tabular}

